[PROC. OF JSCE No. 344/ I -1 (Structural Eng. /Earthquake Eng. ) April 1984]

\title{
A FATIGUE TEST ON THE FULL-SIZE TRUSS CHORD
}

\author{
By Hirosuke SHIMOKAWA*, Koei TAKENA*, Makoto FUKAZAWA** and Chitoshi MIKI***
}

\begin{abstract}
One box-section member whose dimensions are almost equal to the truss chord of Iwakurojima Bridge, (the world's longest cable-stayed bridge) has been fabricated. The fabrication process of the bridge has been evaluated throughout the construction and the member is used in the following fatigue test. The dimension of the member is $1000 \mathrm{~mm}$ wide and $1000 \mathrm{~mm}$ high, and a $600 \mathrm{MPa}$ class steel of $45 \mathrm{~mm}$ thickness is used. The corner joints of this member contain groove welds with partial penetration from outside and fillet welds from inside. The fatigue test is carried out under the four point bending method by a fatigue testing machine with the dynamic capacity of $4 \mathrm{MN}$. Fatigue cracks originate from the location of distinct surface ripples in the stop-and-start position of the inside fillet welds in the corner joints and in several positions in the member.
\end{abstract}

\section{INTRODUCTION}

Many long-span suspension bridges, cable-stayed bridges and truss bridges to be constructed under the HonshuShikoku Bridges project. The stiffened-girders of all suspension bridges and the decks of all cable-stayed bridges in this project are steel truss structures with box-section chords. The fatigue strengths of truss chords made of highstrength-steels, longitudinal welded joints (180 mm wide, $45 \mathrm{~mm}$ thick) ${ }^{1)}$ and box-section members $(180 \mathrm{~mm} \times 300$ $\mathrm{mm}, 15 \mathrm{~mm}$ thick) ${ }^{2)}$ with partially penetrated corner welds were tested with a $4 \mathrm{MN}$ fatigue testing machine, and the fatigue design code and the fabrication code for Honshu-Shikoku Bridges ${ }^{3)}$.4) were established on the basis of the results of these tests.

Box section truss chords are usually built up by the corner joints of partially penetrated groove welds or fillet welds from the outside, and the sizes of these welds are determined as shown in Fig. 1. The allowable fatigue stress for a corner joint is determined considering this kind of corner joint. However, as for large section truss chords of thick plates, there are some misgivings about the occurrence of secondary stress or unexpected deformation in corner joints because of the weld from the one side of plate and the smallness of weld. Therefore, in some long span steel trusses such as the Minato Bridge (the longest cantilever steel truss in the world, main span of
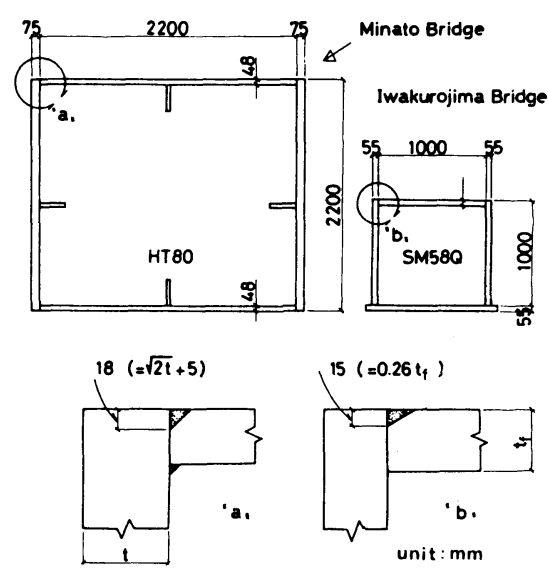

Fig. 1 Cross section of truss chord.

* Member of JSCE, Honshu-Shikoku Bridge Authority (Mori Bld. No. 22, Toranomon 4-3-20, Minato-ku, Tokyo)

** Member of JSCE, Yokokawa Bridge Works ( 88 Shinminato, 'Chiba City, Chiba)

*** Member of JSCE, Dr. of Eng., Tokyo Institute of Technology (2-12-1, Ookayama, Meguro-ku, Tokyo) 
$510 \mathrm{~m}$, four highway trucks, 1974) ${ }^{5)}$, the inside fillet welds together with the outside wlds were used as shown in Fig. 1.

Iwakurojima Bridge, which comes under the Honshu-Shikoku Bridge project, is a cable-stayed bridge with a main span of $420 \mathrm{~m}$, and four highway lanes on the upper deck, four railway truck on the lower deck. The truss chords of this bridge are $1000 \mathrm{~mm}$ wide and $1000 \mathrm{~mm}$ high, and $600 \mathrm{MPa}$ class high-strength steels of $55 \mathrm{~mm}$ thick is used. In order to prove the appropriateness of the fabrication procedure for this bridge, one box-section member whose dimensions are almost equal to the truss chord of this bridge, was trially fabricated. Corner joints of this member were welded from both the inside and outside. This member was then used in a fatigue test after the fabrication investigation. The objectives of this fatigue test were to investigate the fatigue behavior of the corner jojnts with inside fillet welds.

\section{SPECIMEN AND TEST METHOD}

Although a truss chord is an axially loaded member, this test was carried out under four-point bending. The test set-up is shown in Fig. 2. The configuration and dimensions of the box-section specimen and the test method are shown in Fig. 3.

The specimen was made of SM58Q steels. Mechanical properties and chemical compositions of these steels are

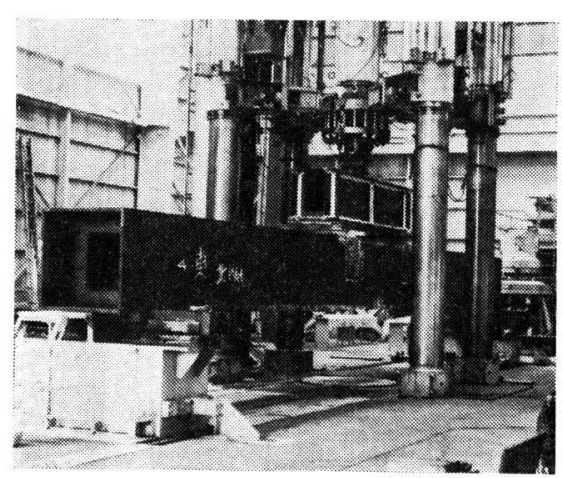

Fig. 2 Test set-up.

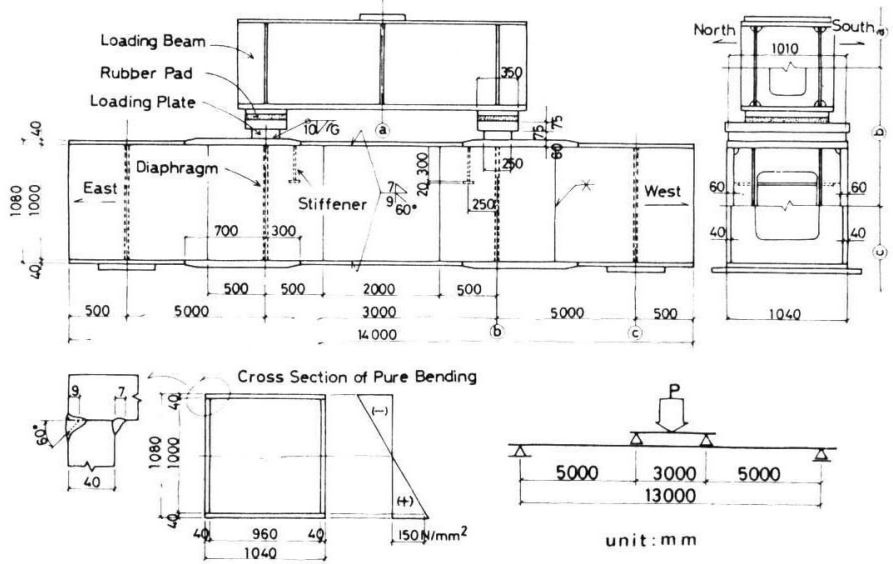

Fig. 3 Configration and dimensions of box-section specimen.

Table 1 Mechanical properties and chemical compositions of steels in test.

\begin{tabular}{|c|c|c|c|c|c|c|c|c|c|c|c|c|c|c|c|}
\hline & \multicolumn{3}{|c|}{ Mechanical Properties } & \multicolumn{11}{|c|}{ Chemical Composition $(\%)$} & \multirow[b]{2}{*}{ Remark } \\
\hline & $\begin{array}{r}\text { Yiefd Point } \\
\text { Nimm }\end{array}$ & $\begin{array}{c}\text { Tensile Strengt } \\
\mathrm{N} / \mathrm{mm}^{2}\end{array}$ & $\begin{array}{c}\text { Elongation } \\
\%\end{array}$ & \begin{tabular}{|c|} 
\\
$\times 100$ \\
\end{tabular} & $\begin{array}{c}\mathrm{Si} \\
\times 100 \\
\end{array}$ & $\begin{array}{c}\mathrm{Mn} \\
\times 100 \times \\
\end{array}$ & $\stackrel{P}{P}$ & $\begin{array}{c}5 \\
\times \infty 000\end{array}$ & $\begin{array}{r}\text { Mo } \\
9 \times 100 \\
\end{array}$ & $\begin{array}{l}\mathrm{Cu} \\
\times 100\end{array}$ & $\begin{array}{l}\mathrm{Cr} \\
\mathrm{x} \infty 00 \\
\end{array}$ & $\begin{array}{c}\mathrm{Ni} \\
\times \infty 00 \\
\end{array}$ & $\begin{array}{c}V \\
0000\end{array}$ & $\begin{array}{l}8 \\
\times 000 \\
\end{array}$ & \\
\hline$S M 58 Q, t=40$ & 588 & 667 & 26 & 14 & 32 & 135 & 18 & 4 & 10 & 10 & - & 14 & 42 & 1 & Flange \\
\hline SM58Q, $t=40$ & 539 & 637 & 29 & 14 & 32 & 135 & 18 & 4 & 10 & 10 & - & 14 & 42 & 1 & Web \\
\hline SM58Q, $t 250$ & 618 & 696 & 24 & 43 & 28 & 131 & 13 & 3 & 15 & - & 13 & - & 39 & 1 & $\begin{array}{l}\text { Flange } \\
\text { Web }\end{array}$ \\
\hline
\end{tabular}

Table 2 Welding conditions of corner joints.

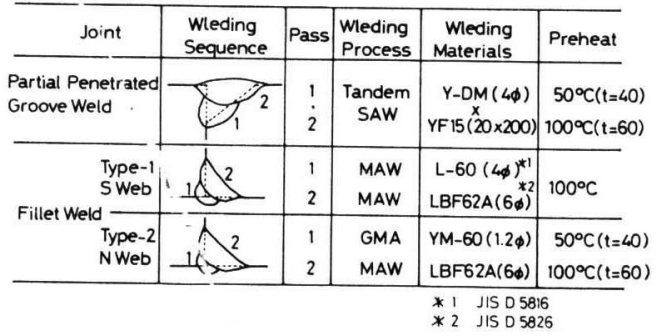

shown in Table 1. Table 2 shows corner joint welding conditions.

The corner joints of this specimen consist of groove welds with partial penetration from the outside (out-side welds) and fillet welds from the inside (inside welds). The out-side welds were performed by a tandem submerged arc welding process. As shown in Table 2, there are two types of inside fillet welds. The first pass of type-1 inside fillet welds was done by manual arc welding for the upper and lower corner joints of the "north" side of the specimen and the first pass of type- 2 inside fillet welds was done by a $\mathrm{CO}_{2}$ arc welding process for the corner joints of the "south" side of specimen. 
Inside fillet welding was done first.

Table 3 Testing conditions.

A testing machine with a $4 \mathrm{MN}$ dynamic capacity was used for the fatigue test. Test conditions are shown in Table 3. Under this load, the nominal bending stress range at corner joints in the region of the central $2000 \mathrm{~mm}$ of the specimen is about $150 \mathrm{MPa}$. The stress range was halved every 500000 cycles so that beach marks would remain on the fracture surface. Fatigue cracks were visually observed every $10^{5}$ cycles. After the fatigue test, residual stresses were measured using the relaxation method.

\section{SUMMARY OF TEST RESULTS}

The fatigue test was done to 1695000 cycles when one fatigue crack penetrated though the lower flange. Fig. 4 shows this fatigue crack. This photograph was taken at the end of the fatigue test. The fatigue crack originated from a pronounced surface ripple in the start-stop

\begin{tabular}{|c|c|c|c|c|c|c|}
\hline \multicolumn{2}{|c|}{$\begin{array}{c}\text { Load } \\
\text { tf }\end{array}$} & \multicolumn{3}{|c|}{$\begin{array}{l}\text { Stress at Root of } \\
\text { Corner Weld, N/mm² }\end{array}$} & \multirow[t]{2}{*}{ Cycles per min. } & \multirow{2}{*}{$\begin{array}{l}\text { Cycles at } \\
\text { Completion of Test }\end{array}$} \\
\hline $\operatorname{Max}$ & Min & $\operatorname{Max}$ & Min & Range & & \\
\hline 362 & 5 & 152 & 2 & 150 & 30 & $169.5 \times 10^{4}$ \\
\hline
\end{tabular}

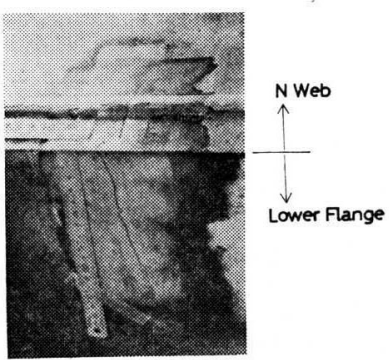

Fig. 4 Fatigue crack penetrated through the lower flange (at 1695000 cycles). position in the manual arc fillet weld.

After the fatigue test, fatigue cracks were observed on the surface of the specimen by the magnaflux inspection method. Furthermore, in order to observe fatigue cracks which had originated at the roots of corner joints, the roots of the outside welds and inside fillet welds were exposed along the weld line as shown in Fig. .6. Various kinds of fatigue cracks were found throughout this spicemen.

\section{FATIGUE CRACKS IN CORNER JOINTS}

All the fatigue cracks in the corner joints are summarized in Fig. 5. None were found in partially penetrated groove welds, ie, all were in the inside fillet welds. Fatigue cracks in corner joints can be classified into four types, as follows.

(1) Fatigue crack from blowhole at the roots of fillet welds.

(2) Fatigue cracks from pronounced ripples in the stop-and-start position in manual fillet welds.

(3) Collective fatigue cracks at the roots of fillet welds.

(4) Longitudinal fatigue cracks along fillet welds.

\section{(1) Fatigue Cracks from Blowholes (Type 1)}

Many blowholes were observed at the roots of the inside fillet welds and outside partially penetrated groove
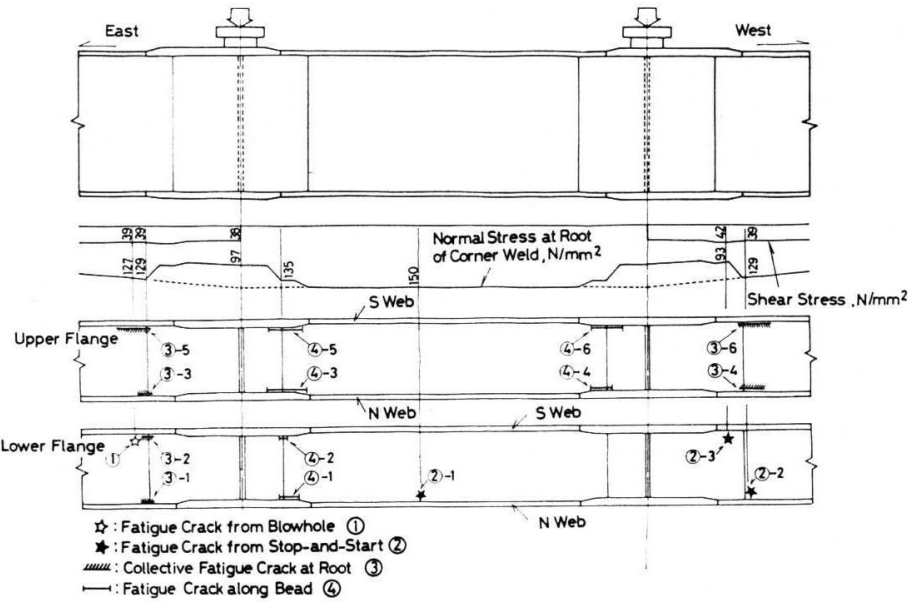

Fig. 5 Fatigue cracks in the corner joints

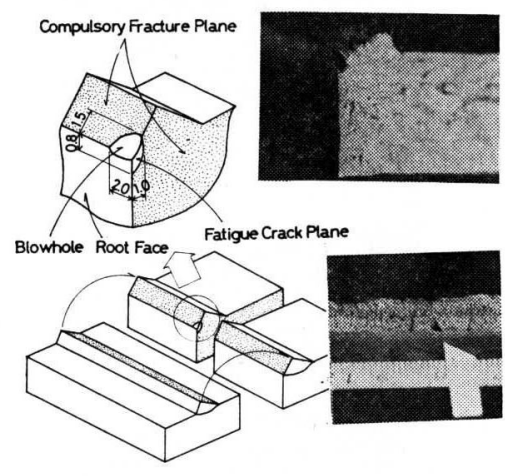

Fig. 6 Fatigue crack originated from blowhole 
Table 4 Size and number of blowholes

\begin{tabular}{|c|c|c|c|c|c|c|c|c|c|c|c|c|c|c|c|c|c|c|}
\hline \multirow{2}{*}{$\begin{array}{l}\text { Size of Width, } w(\mathrm{~mm}) \\
\text { Blowhole } \\
\quad \text { Height, } h(\mathrm{~mm}) \\
\end{array}$} & \multicolumn{4}{|c|}{$\leq 0.5$} & \multirow{2}{*}{\multicolumn{3}{|c|}{$\begin{array}{c}\leq 1.0 \\
\leq 0.5 \leq 1.0 \leq 1.5>\end{array}$}} & & \multirow{2}{*}{\multicolumn{3}{|c|}{$5 \leq 0.5 \leq 1.0 \leq 1$}} & & \multirow{2}{*}{\multicolumn{4}{|c|}{$\leq \leqslant \leq 1.0 \leq 1.5>1.5$}} & \multirow{2}{*}{$\begin{array}{l}\text { Total } \\
\text { Number }\end{array}$} & \multirow{2}{*}{$\begin{array}{l}\text { Length of } \\
\text { Observation }\end{array}$} \\
\hline & $\leqq 0.5$ & $\leq 1.0$ & $\leq 1.5$ & $>1.5$ & & & & $>1.5$ & & & & $\begin{array}{l}5 \\
\leq 15\end{array}$ & & & & & & \\
\hline $\begin{array}{c}\text { Partial Penetrated } \\
\text { Groove Weld }\end{array}$ & 5 & 1 & 0 & 0 & 3 & 4 & 0 & 0 & 0 & 1 & 1 & 0 & 0 & 0 & 1 & 1 & 17 & $17.3 \mathrm{~m}$ \\
\hline $\begin{array}{c}\text { Fillet Weld } \\
\text { Number of (Type-1) } \\
\text { Blowhole }\end{array}$ & 14 & 6 & 2 & 2 & 16 & 9 & 2 & 4 & 7 & 2 & 1 & 0 & 0 & & $0 \times 1.5)$ & 1 & 70 & $9.0 \mathrm{~m}$ \\
\hline $\begin{array}{r}\text { Fillet Weld } \\
\text { (Type-2) }\end{array}$ & 15 & 0 & 1 & 0 & 6 & 14 & 1 & 0 & 0 & 1 & 2 & 1 & 0 & 0 & 0 & 1 & 42 & $8.9 \mathrm{~m}$ \\
\hline
\end{tabular}

welds. Table 4 shows the size and number of blowholes in each weld. The tolerable size of a blowhole for a class A truss chord member of Iwakurojima Bridge is $1.5 \mathrm{~mm}$ wide $(w)$ and $4 \mathrm{~mm}$ high $(h)$ ". One blowhole in each weld is therefore over this tolerance. The rate of occurrence of blowholes is also shown in Table 4. There is a tendency for blowholes to be produced in fillet welds due to the manual arc welding process.

One fatigue crack originated from the blowhole at the root of the inside fillet weld in the "north" side corner joint of the lower flange (1) in Fig. 5). Fig. 6 shows this fatigue crack, which started from the side wall of the blowhole, and its shape is only a quarter circle with a radius of $1.0 \mathrm{~mm}$.

\section{(2) Fatigue Cracks in Stop-and-start Positions (Type 2)}

Three fatigue cracks initiated from the pronounced surface ripple in the stop-and-start position of the inside fillet welds. Fatigue crack (2)-1 (see Fig. 5) was discovered at 1325000 cycles and penetrated through the lower flange at 1673000 cycles. The observation of this crack propagation was continued to 1695000 cycles. The other two fatigue cracks were discovered by close observation after the fatigue test. Fig. 7 shows the appearance of two stop-andstart positions ; (a) is the starting-point of fatigue crack (2) -1 and (b) is the common stop-and-start position in which fatigue cracks did not form. In the stop-and-start position in Fig. 7 (a). there is a notch on the weld surface as a result of the crater, which brought about a pronounced change in the longitudinal profile. The other two fatigue cracks also originated from same surface ripples in the stop-and-start positions. It is therefore necessary to prevent the leaving of crater in the stop-and-start position of a longitudinal fillet weld.

Fig. 8 shows these three fracture planes. These are almost circular and their center are on the surfaces of the fillet weld beads. Beach marks at 1500000 cycles were left on the fracture surface of fatigue cracks (2) -1 and (2) -2 .

\section{(3) Collective Fatigue Crack at Root (type 3)}

At the root of a fillet weld, the collective fatigue crack as shown in Fig. 9 were found. This group of cracks originated near the butt joints of both of the upper or lower flange. These fatigue cracks were found only outside the middle pure bending span, there are no fatigue cracks of this kind in the region of the pure bending span. Fig. 10
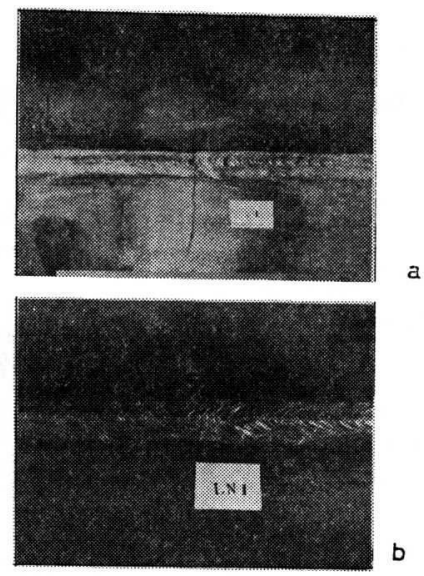

Fig. 7 Appearance of stop-and-start positions. (a: with fatigue crack $\mathrm{b}:$ no-crack)

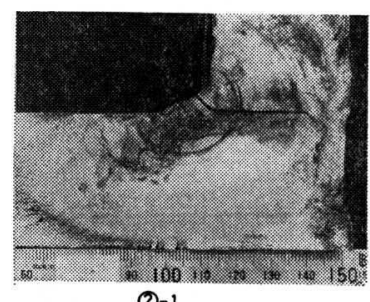

(2)-1

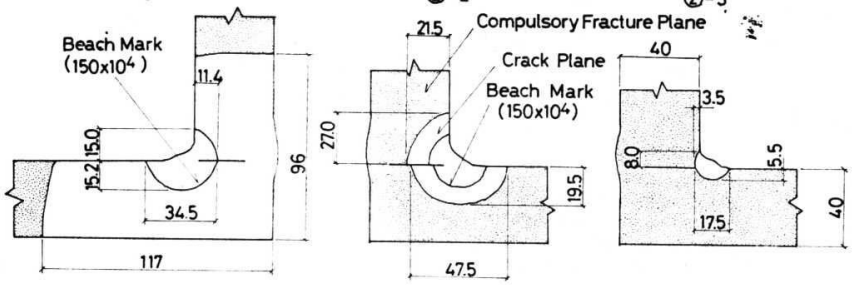

Fig. 8 Fatigue fracture planes from stop-and-start positions. 

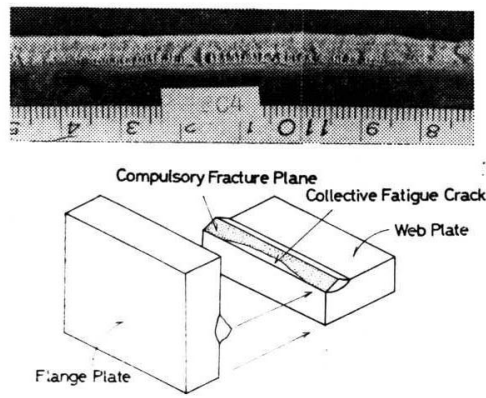

Fig. 9 Collective fatigue crack at root of fillet weld.

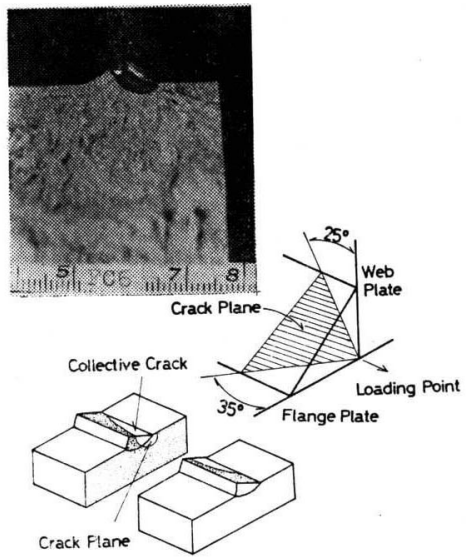

Fig. 10 Fracture plane of a collective crack.

shows the fracture surface of one of these cracks. This crack propagates more deeply into the weld metal of the fillet weld than into the base metal of the flange and at a certain angle to the direction of the weld line. Okada and others $^{(i)}$ showed the same type of fatigue crack in a fatigue test on a butt welded specimen containing an oblique notch. We consider that the occurrence of such cracks is the result of the repetition of mixed stresses, normal stress and shear stress. The mechanism of origination and growth of such cracks, however, must be fully investigated in future studies.

\section{(4) Fatigue Cracks Along the Weld Bead (type 4)}

Near the butt joints of the both of upper and lower flanges, fatigue cracks in the longitudinal direction of the weld bead were appeared on the surface of inside fillet welds after 500000 cycles. Fig. 11 shows one of these cracks. In order to continue the fatigue test, these fatigue cracks were removed by ganging and grinding. On that occasion, we observed two types of fatigue crack. One initiated from the root of an inside fillet weld and propagated into the throat section longitudinally, appearing on the surface of the weld bead in the final stage. The other type initiated from the toe of the fillet weld and propagated into the flange plate longitudinally.

After the discovery of these cracks, the fatigue testing was interrupted and the deformation and stresses of flange and web-plates were examined under static loading. The out-of-plane deformation of flange and web plates was measured near loading points. Large secondary stresses due to this out-of-plane deformation had been applied to the corner joints. Fig. 12 shows stresses measured on the surface of inside fillet welds. This out-of-plane deformation was thought to be due to the fact that the width of the loading plate was smaller than the space between two web plates. Therefore, the loading plates were replaced with larger ones and stiffeners were added on the flange and web plates in order to restrain the out-of-plane deformation.
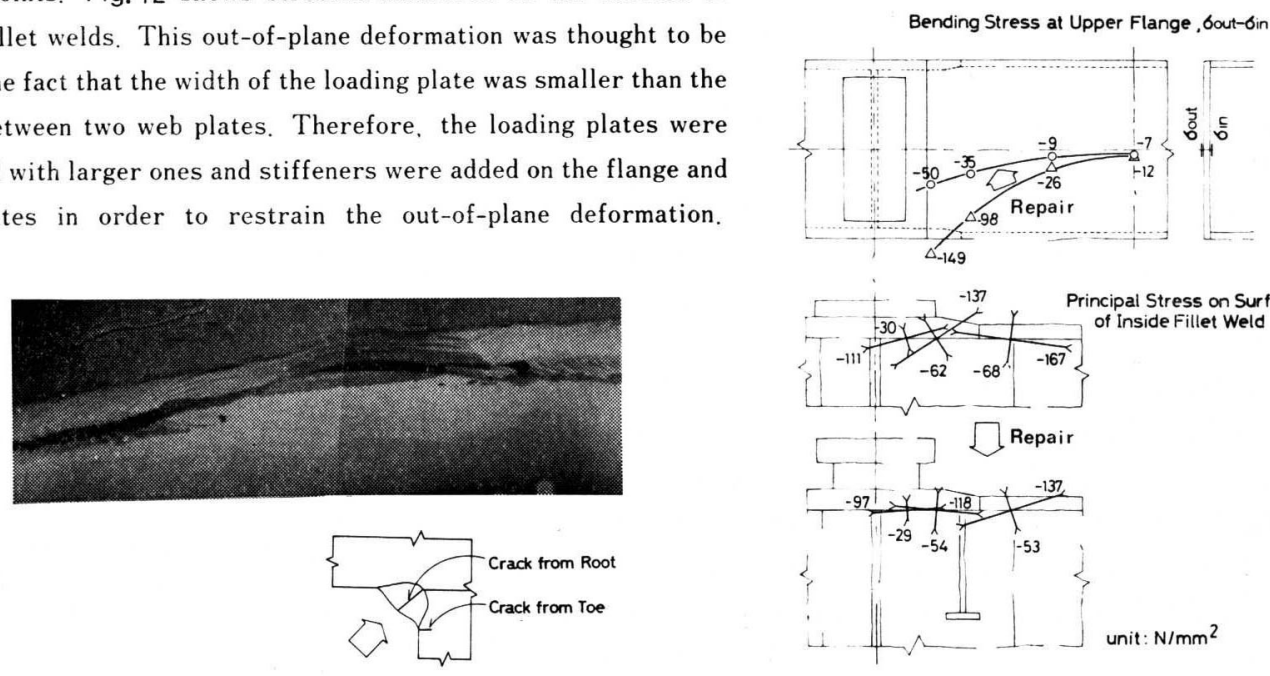

Fig. 11 Fatigue crack along the fillet weld bead

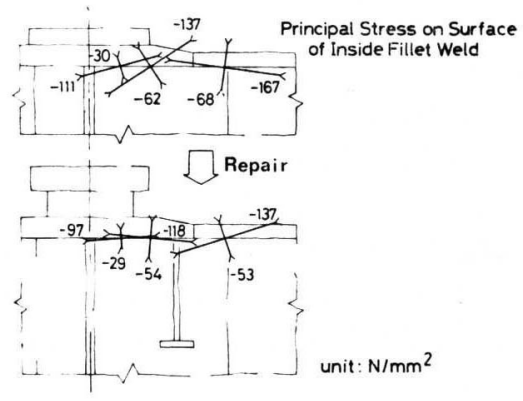

Fig. 12 Measured stress near loading point. 
Furthermore, the throats of fillet welds were thickened and the toes of fillet welds were finished by grinding.

After this repairing of the specimen, deformation and stress were measured again (Fig. 12). The out-of-plane deformation of the upper flange was relatively small but the shear stresses of the fillet weld was not markedly different from these before repairing. Consequently these shear stresses are supposedly caused by the transition in the flange plate thickness.

\section{(5) Fatigue Strength of Corner Joints}

As mentioned above, there were 16 fatigue cracks, which could be classified into four types in the inside fillet welds. Of these, collective crack and cracks along the bead were fatigue cracks particular to this bending test, caused by the characteristic configuration of specimen and the loading method. Therefore. fatigue cracks caused by the quality of corner welding are the fatigue cracks from blowholes and from craters at the stop-and-start positions. In the fatigue design code for Honshu-Shikoku Bridges, corner joints of SM58 steel is classified into category B. The relationship between the design allowable stress range $\left(S_{r}\right)$ and the number of cycles $(N)$ for welded joints in category B expressed as follows.

\section{$\left(S_{r}\right)^{3} \mathrm{~N}=4.10 \times 10^{9} \quad\left(S_{r}: \mathrm{kg} / \mathrm{mm}^{2}\right)$}

This allowable disign curve is based on the results of many fatigue tests on longitudinal welded joints, box-section members, models of truss panel-point structures and fracture mechanics analysis. This curve is shown in Fig. 13. The stress ranges and fatigue life of type 1 and 2 fatigue cracks are plotted in Fig. 13. The stress range is the range of nominal bending stress at the location of each fatigue crack. The fatigue life is the number of cycles at which a fatigue crack propagates to $80 \%$ of the thickness of the web-plate or flange-plate. The fatigue life of each fatigue crack is estimated on the basis of the following assumption using the fracture mechanics concept.

(a) fatigue crack from blowhole shown in Fig. 6.

The fatigue crack is in the shape of an quater circle in radius of $10 \mathrm{~mm}$ at $169.5 \times 10^{3}$ cycles. Eqnation (1) is used in the calculation of the fatigue life as the relationship between the fatigue crack growth rate $(d a / d N)$ and the stress intensity factor range $(\Delta K)$.

$$
\begin{aligned}
& d a / d N=C(\Delta K)^{m} \ldots \ldots \ldots \ldots \ldots \ldots \ldots \ldots \ldots \ldots \ldots \ldots \ldots \ldots \ldots \ldots \\
& \text { where } m=3 \\
& C=1.63 \times 10^{-10}\left(d a / d N: \mathrm{mm} / \text { cycle, } \Delta K: \mathrm{kgf} / \mathrm{mm}^{3 / 2}\right)
\end{aligned}
$$

(b) fatigue cracks from stop-and-start positions shown in Fig. 8.

The fatigue cracks are semi-elliptical (in the flange-plate), and quarter circle (in the wed-plate), and each in a crack progressed independently as shown in Fig. 14. The initial size of fatigue crack in the fracture mechanics analysis is the size of the beach mark at $1500 \times 10^{3}$ cycles for cracks (2) -1 and the crack sizes at $1695 \times 10^{3}$ cycles for crack (2) -2 and (2) -3 .

The fatigue life of each crack is calculated in the web and flange plate respectively, and the shorter one was regarded as its estimated fatigue life. Eq. (1) is used in the calculation of fatigue life.

In Fig. 15, the result of the fatigue crack from a blowhole is plotted beyond the fatigue design curve toward the longer-life side. This result is consistent with the resuts of previous tests on box-section members with $300 \times 180 \mathrm{~mm}$ section made of $16 \mathrm{~mm}$ thick $600 \mathrm{Mpa}$ class steel. However, the results of fatigue cracks (2) -3 and (2) -2 are plotted below the design

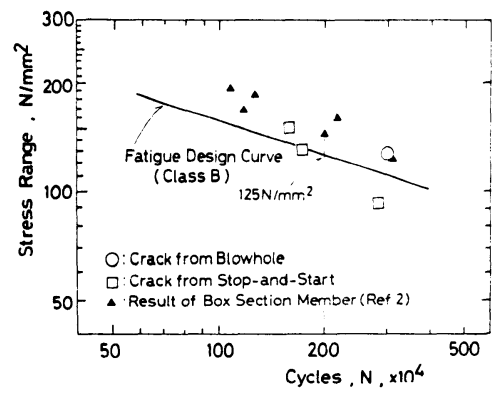

Fig. 13 Test results and fatigue design curve

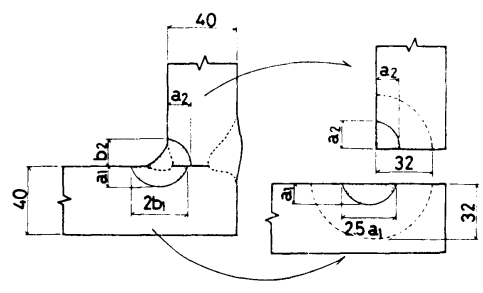

Fig. 14 Illustrative crack configuration

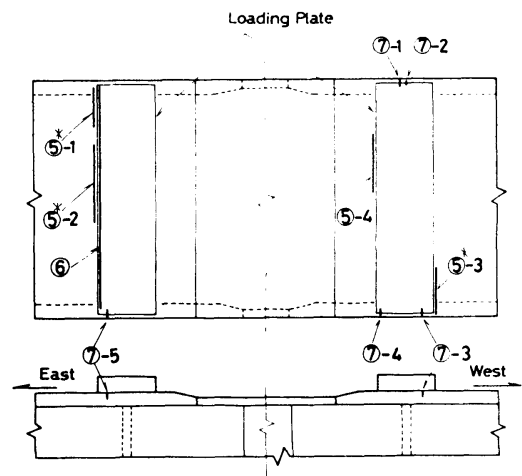

(5) Crack from Weld Toe of Transvere Fillet Weld (6) Crack from Weld Root of Transvere Fillet Weld (7) Crack across Bead of Longitudinal Weld (*, Repair during Test )

Fig. 15 Fatigue cracks around the loading plates on the upper flange 
curve. Therefore, a pronounced ripple or crater. as shown in Fig. 7. a, must not remain on an inside longitudinal fillet weld, when the design curve for category B is employed.

\section{FATIGUE CRACKS BESIDES THOSE IN CORNER JOINTS}

Fatigue cracks occur not only in corner joints, but may originate in several positions in a specimen. These cracks are supposedly caused by the loading method particular to this test. and the main objective of this experiment was to study the fatigue properties of corner joints with inside fillet welds. But the behavior of these cracks suggests that the design and fabrication of the weld structure are to blame because of the analogy between the details and dimensions of this specimen and as well as the actual structures.

Fig. 15 shows fatigue cracks around the loading plates on the upper flange. In this region, repeated bending stress was compression-compression. All fatigue cracks originated from, and propagated perpendicular to the axis of the specimen. These cracks can be classified into three types as follows.

Type 5: cracks from the weld toe of a transverse fillet weld (Fig. 16)

Type $6:$ cracks from the weld root of a transvere fillet weld (Fig. 17)

Type 7 : cracks across the bead of a longitudinal weld (Fig. 18)

Four type 5 fatigue cracks appeared along the toe of the transverse fillet weld on the upper flange. The toe ot this weld was made smooth by grinding. Three of four cracks were observed during the fatigue test, and repaired by gouging and welding. Fig. 16 shows the fatigue crack surface of crack (5) -4 . which was detected after the fatigue test and exposed for observation. This fatigue crack started from the toe of the transverse fillet weld and penetrated into the flange plate as a flat semi-ellipse shaped crack.

Type 6 fatigue cracks initiated at the root of the transverse fillet weld and propagated to both the fillet weld and the flange plate. Fatigue cracks towards fillet weld penetrated through the weld bead. Fatigue cracks towards the flange plate almost penetrated through the flange plate.

Type 7 fatigue cracks started from the root of the longitudinal fillet weld and then appeared on the surface of the weld bead.

Fig. 19 shows the fatigue crack which originated at the toe of fillet weld at the scallop of the vertical stiffener. This stiffener was added after type 4 fatigue cracks were observed, to prevent the out-of-plane deformation of the
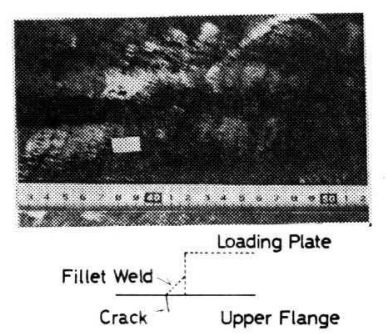

Fig. 16 Fatigue crack from the weld toe.

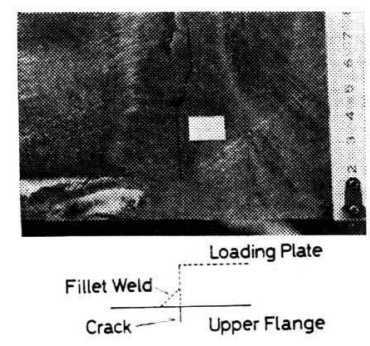

Fig. 17 Fatigue crack from the weld root.
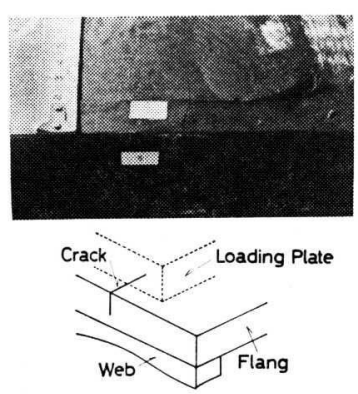

Fig. 18 Fatigue crack across the bead.

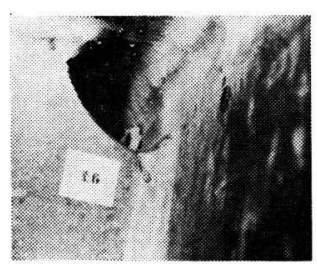

Fig. 19 Fatigue crack at the scallop of the vertical stiffener. upper flange and web.

\section{DISTRIBUTION OF WELDING RESID- UAL STRESS AT CORNER JOINTS}

The measurement of residual stresses was carried out on a section in a position $1.25 \mathrm{~m}$ from the end of the beam.

Fig. 20 shows the distribution of residual stress in a quarter section. High tensile residual stresses

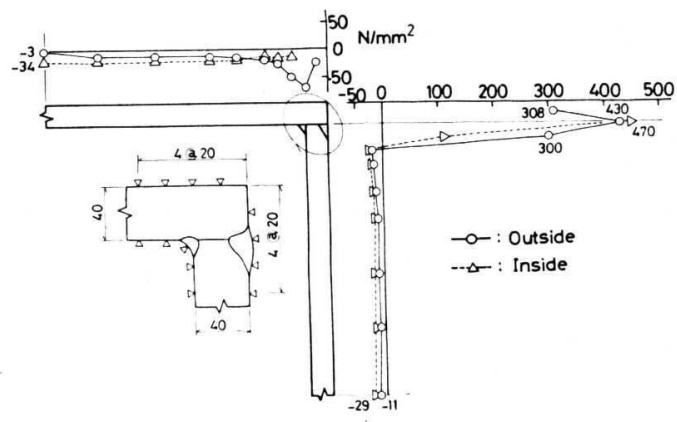

Fig. 20 Distribution of residual welding stress. 
were introduced near corner welds. where the maximum stress being on the bead, was $430 \mathrm{~N} / \mathrm{mm}^{2}$ on the outside welds and $470 \mathrm{~N} / \mathrm{mm}^{2}$ on the inside welds.

\section{SUMMARY}

The results of this test are summarized as follows.

1) Between the outside partially penetrated groove weld and the inside fillet weld, there was not significant difference in quality, supposing the occurrence of large blowholes whose size is over the tolerance size. But, blowhols are apt to occur in fillet welds due to the manual arc welding process.

2) Three fatigue cracks started from pronounced ripples in the stop-and-start positions where small craters were left in the manual fillet welds of a corner joint. One fatigue crack originated from a blowhole in the manual fillet weld of a corner joint. No fatigue crack originated in the outside partially penetrated groove welds and the inside fillet welds by $\mathrm{CO}_{2}$ welding process of a corner joint.

3) Near the loading points the fatigue cracks at the root of the inside fillet weld of a corner joint. These cracks are supposedly caused by the combination of shear and normal stresses due to the transition in the flange-plate thickness. The longitudinal fatigue cracks along the fillet weld caused by the out-of-plane deformation of the flange and web plate also originated from the fillet weld near the loading points.

4) In the $S-N$ diagram, the relationship between the stress range and fatigue life of the fatigue crack from a blowhole in a longitudinal fillet weld is plotted beyond the category B fatigue design curve. However, two of three fatigue cracks from ripples in the stop-and-start positions in longitudinal fillet weld are plotted below the category $\mathrm{B}$ design curve. Therefore, pronounced ripples must not remain on longitudinal fillet welds, when category $\mathrm{B}$ design curve is employed.

5) Not only did fatigue cracks occur in corner joints, but many fatigue cracks originated around the loading plates on the upper flange and at the toe of the fillet weld at the scallop of the vertical stiffener.

\section{ACKNOWLEDGEMENTS}

The fatigue test was carried out in the Japan Construction Method and Machinery Research Institute. The authors would like to thank Messrs. Y. Eguchi, S. Tanifuji and F. Itoh of the Japan Construction Method and Machinery Research Institute for their efforts in the experimental work.

They would also like to express their gratitude to $\mathrm{Dr}$. S. Akashi, Mr. H. Terada and Mr. T. Natori of the Yokogawa Bridge Works for their valuable suggestions.

\section{REFERENCES}

1) Miki, C. Tajima, J. Asahi K. and Takenouchi, H. : Fatigue of Large-sized Longitudinal Butt Welds with Partial penetration. Proc. of JSCE. No. 322. 1982.

2) Tajima. J., Asama, T. Miki. C. and Takenouchi, H. : Fatigue of Nodal Joint. Box-Section Truss Chords and Large Welded Joints, Colloquim IABSE. March 1982.

3) Japan Society of Civil Engineers, Committee for Honshu-Shikoku Bridges : Study on Fatigue, 1983 (in Japanese)

4) Technical Committee for the Constrction of Honshu-Shikoku Bridges, Kaiyoh Kakyo Chohsakai : Technicl Report for the Construction of Stiffened Truss. 1982 (in Japaese).

5) Sasado, S. . Yoshikawa. N. Kawai. A. and Mizumoto, Y. : Design and Construction of Corner Joint on Large Span Truss Bridge, Journal of The Bridge and Foundation Engineering. No. 3, 1975. (in Japanese)

6) Okada. M. and Moriwaki. Y. : On the Fatigue Behavior of weld Joint Containing a Notch-Report 3, Journal of J. W. S. vol. 31. No 6. 1962 (in Japanese)

(Recieved August 31, 1983) 